\title{
Quality Water is Issue for Healthy Life and Planate
}

\author{
Muzammel Hossain* \\ Sharklab International and Sharklab ADRIA, Europe
}

Submission: February 03, 2017; Published: February 10, 2017

*Corresponding author: Muzammel Hossain, Sharklab International and Sharklab ADRIA, Europe, Email: muzammel@sharklab-adria.org \& muzammel3@gmail.com

\section{Introduction}

Hello, my name is Md. MuzammelHossain and I serve as a research scientist with Sharklab International and Sharklab ADRIA. My experience series establish from different multidisciplinary topic on freshwater and marine water. Water war is an upcoming future war. All animal is depending on water. Water is not sacrifice in any religion and it has no color. It's alive for all human being in the planate. It's moveable around the world.

If you are wanting to healthy life need to conserve clear water. My purpose for this article is to further awareness on freshwater and marine water conservation properly for each animal. We were examining of human health risk assessment in tropical fish and shellfish collected from BurigangaRiver, Dhaka [1] because during the past several decades the increasing usage of heavy metals in industry has led to serious water pollution through effluents and emanations [2]. Heavy metals are a global concern, due to their potential toxic effect and ability to bioaccumulate in aquatic ecosystems $[3,4]$. This assessment study was very interesting for me. Buriganga river is a polluted river in Bangladesh and it sometime contain freshwater that is can't control through the year. Aquatic animal in Buriganga can accumulatemetals in its tissues through absorption, and humanscan be exposed to these metals via the food web that's why freshwater is important in the world. Different types of people and children was collect fishes and shellfish during rainy season that can continuously consume fish and other aquatic organism contaminatedwith metals as initiate in the study are underthe target cancer risk in the long run.

The little is known about the poverty level of fisherman of the area who is dependent on the river for their livelihood

especiallydry season there is no fish in Buriganga River. Livelihood diversification with children is also affected by each household's participation in strategies to manage natural resources around the river area. So that most of the fisherman has been migrated from the area for health risk and polluted river [5]. During the study period under Jagannath University, Dhaka both type of water habitat and two type of life style was found around the BurigangaRiver [6]. Additionally our children in the area have a critical situation for polluted water. Not only child also mammal animal river dolphin in the river has a defenseless. I think nutrition and food is most important which consists ofproteins, fats, carbohydrates, minerals, salts, vitamins, fiber andenzymes, in addition to water. But healthy life and healthy planate is not possible without freshwater water. Water is one of the most important substances on earth. All plants and animals must have water to survive in the earth. If there was no water there would be no life on earth.

\section{References}

1. Ahmed MK, Baki MA, Islam MS, Kundu GK, Habibullah-Al-Mamun M, et al. (2015) Human health riskassessment of heavy metals in tropical fish and shellfish collected from the river Buriganga, Bangladesh. Environ SciPollut Res 22(20): 15880-15890.

2. David IG, Matache ML, Tudorache A, Chisamera G, Rozylowicz L, et al. (2012) Food chain biomagnification of heavy metals insamples from the Lower Prut Floodplain Natural Park. Environ Eng Manag J 11(1): 69-73.

3. Batvari B, Prabhu D, Kamalakannan S, Krishnamurthy RR (2015) Heavy metals accumulation in two fish species (Labeorohita and Cirrhinamrigala) from Pulicat Lake, North of Chennai, Southeast Coast ofIndia. J Chem Pharm Res 7(3): 951-956.

4. Baki MA, Islam MR, Hossain MM, Bhouiyan NA (2015) Livelihood status and assessment of fishing community In adjacent Area Of TuragBuriganga River, Dhaka, Bangladesh. International Journal of Pure and Applied Zoology 3(4): 347-353.

5. SericanoJL, Wade TL, Jackson TJ (1995) Trace organic contamination intheAmericas: an overview of the US National Status, Trends and theInternational Mussel Watch Programmes. Mar Pollut Bull 31(4-12): 214-225.

6. Hossain MM, Baki MA (2014) Freshwater habitats and fishing activities In the Buriganga River, Dhaka, Bangladesh. HydroMedit 2014, November 13-15, Volos, Greece, pp. 318-323. 
(C) (i) This work is licensed under Creative BY Commons Attribution 4.0 License
Your next submission with Juniper Publishers will reach you the below assets

- Quality Editorial service

- Swift Peer Review

- Reprints availability

- E-prints Service

- Manuscript Podcast for convenient understanding

- Global attainment for your research

- Manuscript accessibility in different formats

( Pdf, E-pub, Full Text, Audio)

- Unceasing customer service

Track the below URL for one-step submission https://juniperpublishers.com/online-submission.php 